
\title{
$\begin{array}{ll}\text { Research Square } & \begin{array}{l}\text { Preprints are preliminary reports that have not undergone peer review. } \\ \text { They should not be considered conclusive, used to inform clinical practice, } \\ \text { or referenced by the media as validated information. }\end{array}\end{array}$
}

\section{Ethnic Differences in Spermatozoa Morphological Defects Diversity Among Men From Eastern Siberia, Russia}

\section{Maxim Kleshchev ( $\square$ max82cll@bionet.nsc.ru )}

Federal Research Center 'Institute of Cytology and Genetics', the Siberian Branch of the Russian Academy of Sciences, 10

Prospekt Lavrentyeva, Novosibirsk 630090, Russia; https://orcid.org/0000-0002-7537-2525

Alexander Osadchuk

Institute of Cytology and Genetics SB RAS: FIC Institut citologii i genetiki Sibirskogo otdelenia Rossijskoj akademii nauk

\section{Larisa Shantanova}

Institute of General and Experimental Biology SB RAS: Institut obsej i eksperimental'noj biologii

\section{Ivan Troev}

North-Eastern Federal University named after M K Ammosov: Severo-Vostocnyj federal'nyj universitet imeni M K Ammosova

\section{Ludmila Osadchuk}

Institute of Cytology and Genetics SB RAS: FIC Institut citologii i genetiki Sibirskogo otdelenia Rossijskoj akademii nauk

\section{Research}

Keywords: sperm morphology, sperm motility, ethnos, sperm morphological abnormality, general population

Posted Date: November 17th, 2020

DOl: https://doi.org/10.21203/rs.3.rs-106034/v1

License: (c) (i) This work is licensed under a Creative Commons Attribution 4.0 International License. Read Full License 


\section{Abstract}

\section{Background.}

Sperm morphology defects are considered to indicate several spermiogenesis anomalies, resulting in decreased men fertility, causing not only poor sperm morphology but also increased DNA fragmentation, chromatin condensation defects, increased oxidative stress. Consequently, detailed assessment of sperm morphological abnormalities in additional to counting percentage of sperm with normal morphology may be useful for andrologists and reproductive biologists. However, a little attention is paid to studying a regional and especially ethnic variability in the incidence of the sperm morphology defects. The aim of this research was to estimate ethnic variability in percentages of the sperm morphology abnormalities in men from general population living in the Siberian region of the Russian Federation.

\section{Methods.}

Male volunteers of Buryat $(n=195)$, Yakut $(n=130)$, and Slavic $(n=89)$ ethnicity from the general population from Ulan-Ude and Yakutsk at least 5 years were enrolled in the study. Percentages of sperm morphological defects (according to the classification provided by the WHO laboratory manual, 2010) are counted after staining native ejaculate smears by Diff-Quick kits.

\section{Results.}

Among sperm defect, amorphous (62.25 $\pm 12.18 \%)$, elongated $(10.61 \pm 8.62 \%)$, pyriform( $8.61 \pm 9.17 \%)$, and vacuolated heads (10.31 $\pm 6.77 \%)$, abnormal acrosome $(20.43 \pm 12.67 \%)$, asymmetrical insertion neck $(18.33 \pm 6,43 \%)$, thick midpiece $(6.21 \pm 3,41 \%)$, bent head $(5.94 \pm 4,02 \%)$ and coiled tail $(10.8 \pm 6.79 \%)$ were most frequent. In comparison with Buryats, Slavs and Yakuts were characterized by the decreased proportion sperm with normal morphology, the increased proportion of pyriform, elongated heads, abnormal acrosome, asymmertical tail insertion, excessive residual cytoplasm and increased teratozoospermia index (TZI). It was shown that impared progressive sperm motility and concentration associated with decreased percentage of sperm with normal morphology and increased proportion most of sperm morphology defects and TZI. However, increasing TZI in men with oligoastenozoospermia compared to men with astenozoospermia was revealed for Buryats only, suggesting ethnic features in the relationships between sperm morphology and concentration.

\section{Conclusion.}

The present study showed significant coordinated ethnic variability in the percentages of several sperm morphological defects in men from the general population located in Eastern Siberia. Damaged spermiogenesis processes underlying sperm head elongation and tail formation is considered to be significant contributors to geographical and ethnic variability of sperm morphology in men from the studied populations.

\section{Introduction}

It is known that unlike most other mammalian species the majority of spermatozoa in an ejaculate of even healthy men have morphological defects presented in various proportions. It is believed that morphological abnormalities are resulted from the distributions of spermiogenesis due to genetic and environmental factors $[1,2]$.

Due to high sperm morphological diversity in human it is difficult to define sperm appearance which we should consider as normal. However, investigation of sperm overcoming the cervical mucus served as the basis for determining the morphological characteristics of normal sperm, described in the fifth [3] edition of the "WHO laboratory manual for the examination and processing of human semen". The number of studies has been showed that rate of normal sperm correlates with fertilization rate in vitro and in vivo. Currently, the assessment of the proportion of morphologically normal spermatozoa is the important tool for diagnostics of male infertility [1,2,3], the choice of medical tactics when using ART methods [4].

To date several classification systems of sperm defects have been made which considered structural features of head, midpiece and tail [3-6]. Much attention is paid to studying monomorphic teratozoospermia with genetic origin such as globozoospermia, 
macrocephaly, abnormal head-tail attachment, dysplasia of the fibrous sheath $[7,8,9]$. It should be noted that monomorphic teratozoospermia is rare in human population. In particular, the globozoopermia is revealed in less than $0.1 \%$ infertility men [10]. In most cases, several sperm defects are presented in different proportions in ejaculate. It is believed by several authors that sperm defects rates (sperm morphological pattern) are specific for certain men. Morphological pattern is considered to be caused joint influences of genetic and external factors [2]. An increasing incidence of several sperm defects in men suffering from varicocele, genital infections, cryptorchidism, testicular tumors was reported in the earlier studies [1,2]. Acrosome defects, small heads, bent or misaligned tails, excessive residual cytoplasm (ERC) were significantly more frequent in the patients with testicular cancer than in infertile and fertile men [6].The incidence of spermatozoa with an elongated head is also increased in infertile men with varicocele, with urogenital infections and in the case of workers in a reinforced plastic production [11]. An incidence of elongated heads in the men with varicocele was decreased after embolization [12], suggesting reversibility poor sperm morphology as a result of treatment. These findings suggest that the spermiogenesis is sensitive to external factors and an incidence of sperm morphological defects is influenced by an environment and a disease, with the spermiogenesis impairment being reversible, enabling therapy of teratozoospermia.

Moreover, correlations between proportions of several sperm defects and other semen quality indicators such as DNA fragmentation [13-16], chromatin condensation, oxidative stress [15], sperm chromosomal aberrations [17], sperm motility $[18,19]$ were revealed. Sperm with small, multiple and vacuolated heads have uncondensed chromatin more frequently than normal sperm [20]. Abnormal chromatin structure and increased DNA fragmentation were associated with globozoospermia and abnormally small heads [21]. To conclude this findings suggest that sperm morphology defects may be markers of spermiogenesis impairment resulting from external and genetic factors and resulting in not only sperm shape abnormalities but also disruption of chromatin condensation, DNA damage and oxidative stress of sperm. Consequently, counting sperm morphology defect may be good diagnostic tool for male infertility diagnostics, choice of ART methods, as well as basic research of spermiogenesis and its genetic control and external determinants. Nevertheless to date, the results on relation of sperm morphology and other sperm and fertility parameters are contradictory because this relationships have been demonstrated by several authors but refuted by others These discrepancies are considered to result from lack standardization for sperm morphology assessment procedures [1]. However it is possible that observed contradictions in the evidences are caused by the complexity of spermiogenesis process therefore its relationships with external and internal factors widely vary in different human populations. It should be noted that introduction of a computer vision and artificial intelligence technologies can significantly simplify a very time-consuming task of sperm morphology estimation and help to standardize the assessment $[22,23]$. Furthermore, further population researches are needed for making thresholds for the incidences of sperm morphology defects [24] and better understanding genetic and environmental factors affecting spermiogenesis.

However, to date, there is gap in our knowledge about the prevalence of certain morphological abnormalities in the human population, regional and especially ethnic features of sperm morphology pattern. In the late XX - early XXI centuries, the numerous population studies of sperm quality in men were performed in different regions of Europe, North America and Southeast Asia. These studies revealed regional and ethnic differences in sperm count, sperm motility and percentage of morphologically normal sperm [25-30] as well as decreasing semen quality during the last decades [31, 32] and high frequency of sub-optimal sperm quality in men from general population [33]. It is believed that revealed regional and ethnic differences may be caused by the complex influences of various environmental and lifestyle factors [34] as well as genetic features associated with ethnicity. However, there are few population studies including estimation of sperm morphology pattern. To our knowledge single such investigation has been performed by J. Auger et al. studying men with proven fertility living in Turku, Copenhagen, Edinburgh and Paris [24]. Significant differences in the proportion of all sperm morphology defects and multiple anomaly index (MAl) were found despite lack of differences in the percentage of normal sperm. Moreover, this study revealed that an increase of several sperm defects was related to season, medical treatment of mother during pregnancy, increased birth weight, previous treatment for cryptorchidism, stress and other environmental and lifestyle factors. The authors stressed that the reasons of the revealed variability were unknown and further investigations are needed. Moreover, these authors estimated the percentages of sperm morphological defects in fertile men, male partners from infertile couples, and testicular cancer patients and established high, medium and low thresholds for rates of sperm abnormalities [6]. It should be noted that the study [24] considered regional features of sperm morphology only. To our knowledge ethnic features in sperm morphology pattern 
have not been studied until now. However, the number of studies was performed in USA [35, 36] and Eastern Europe [37], which revealed race differences in sperm concentration, sperm motility and incidence of oligozoospermia and astenozoospermia. These studies suggest that ethnicity could be affect spermatogenesis and a probability of its impairment like other biological characteristics and illness [38, 39]. Epidemiological studies including men of different ethnicity living in different regions with various environmental conditions may be helpful for understanding environmental and genetic influences on spermiogenesis, as well as on development national thresholds for an incidence of sperm morphology defects.

It should be noted that epidemiologic studies of semen quality in men from the Russian Federation are rarely conducted [40 42]. However, the Russian Federation located on the Eurasian continent is characterized by various environmental conditions and ethnic groups and may be interesting for studying environmental and genetic influences on spermiogenesis.

The aim of this research was to estimate effect of ethnicity on the incidence of sperm morphology abnormalities in men from the general population living in the Siberian region of the Russian Federation as well as interrelation of sperm morphology with sperm motility and concentration.

To solve this problem, the standardized investigation of sperm quality and the proportion of various sperm morphology defects were performed in men living in Ulan-Ude and Yakutsk. These cities located in Eastern Siberia are the places of compact residence of the Buryats (Ulan-Ude) and the Yakuts (Yakutsk) being the indigenous ethnic groups for these regions as well as men of the Slavic ethnicity living in Ulan-Ude and Yakutsk.

\section{Materials And Methods}

Study population. Male volunteers $(n=414)$ from the general population living in the cities of Ulan-Ude and Yakutsk at least 5 years were enrolled in the study. Men were informed about the study through an advertisement at the Internet and the universities. Inclusion criteria for participation in the study were absence of acute general or chronic diseases in an acute phase, genial tract infections and medicine use. In a preliminary telephone conversation, each participant was informed about a necessity of sexual abstinence and an abstention from alcohol consumption for 2-3 days before the examination. All volunteers gave an informed consent for a participation in the examination. Each participant was examined by an experienced andrologist and the results of the examinations were recorded in a standard protocol. Secondary sexual characteristics and the possible presence of varicocele, hydrocele or hypospadias, the location of the testis in the scrotum, the consistency of the testis and epididymis were examined to establish a preliminary urological diagnosis. Body weight $(\mathrm{kg})$ was measured with participants wearing light clothing, using an electronic scale. Height was measured using a standard stadiometer. Testicular volume was estimated by a Prader orchidometer. Each participant filled in a standardized questionnaire including information on current age, place of the born, family status, previous or current urological diseases and a history of fertility as well as the nationality of the volunteer and his parents - father, mother, grandmother and grandfather. The participant was attributed to certain ethnos (Buryat, Yakut and Slav) only if all his parents were recorded as the same ethnos. Otherwise the volunteer was attributed to a metis group and excluded from the study. The Slavs ethnic group included the Russians, Ukrainians, Belarusians, Poles. Volunteers of minority ethnic groups for the studied population (Kyrgyz, Evenki, Mari and others) were excluded from the study.

Semen samples. The semen samples were collected by a masturbation into disposable sterile plastic containers in the special privacy room close to the laboratory and were analyzed for semen volume $(\mathrm{ml})$, sperm concentration $(\mathrm{mln} / \mathrm{ml})$, progressive motility (percentage) and sperm morphology. Semen volume, sperm concentration and sperm count were estimated according to the "WHO laboratory manual for the examination and processing of human semen" (WHO, 2010) [3]. The semen samples were kept at $37^{\circ} \mathrm{C}$ not more than $1 \mathrm{hr}$. for liquefaction. Ejaculate volume was estimated by weighing the collection container and subtracting the weight of the empty preweighed container, assuming that $1 \mathrm{ml}$ ejaculate weighs $1 \mathrm{~g}$. To determine sperm concentration, $100 \mu \mathrm{l}$ of well-mixed ejaculate was dissolved in $400 \mu \mathrm{l}$ of the mixture ( $5 \% \mathrm{NaHCO} ; 0.35 \%$ formaldehyde; $0.025 \%$ trypan blue in distilled water). Subsequently, sperm concentration was assessed using a hemocytometer under light microscope (magnification $\times 400$ ). Two hundred sperm in two fields were counted at least. Percentage of progressive motility spermatozoa (WHO motility classes A + B) was estimated in native ejaculate by the automatic sperm analyzer SFA-500 (Biola, Russia). This method for estimating sperm motility has been described earlier [42]. Briefly, the evaluation sperm motility bases on a 
measurement and analysis by special software of optical density fluctuations in native ejaculate as a result of sperm movement through an optical channel illuminated by a laser beam. The sperm motility measurements were carried out three times for each sample and a mean value was calculated.

To study the relationships between impaired semen quality and percentages of sperm morphological defects each participant was assigned to semen quality status (SQS) according to sperm quality thresholds provided by WHO [3] - asthenozoospermia (percentage of progressively motile spermatozoa $<32 \%$ ), oligoasthenozoospermia (sperm concentration $<15 \mathrm{mln} / \mathrm{ml}$ and percentage of progressively motile spermatozoa<32\%) and normozoospermia (sperm concentration and percentage of progressively motile spermatozoa equal to or above the lower reference limits). There are only three men with isolates oligozoospermia which was excluded from the analysis.

Sperm morphology analyses. To assess sperm morphology, the ejaculate smears were prepared, fixed by methanol (during 1 min) and stained using Diff-Quick kits (Abris plus, Russia) according to the "WHO manual..." [3]. Spermatozoa were examined for morphology using an bright-field optical microscope (Carl Zeiss, Germany) at $\times 1000$ magnification with oil-immersion. The microscope was equipped by a digital camera AxioScope with a special software (AxioVision 9.0) enabling to perform a sperm morphometry. Two hundred sperm for each semen sample were assessed twice in random and blinded order by the only experienced researcher.

Sperm morphology classification. The sperm were classified as normal, according the criteria for normal sperm morphology provided by WHO [3]. Other sperm, including borderline forms, referred to as abnormal. The classification of sperm defects was performed according to the classification scheme proposed by "WHO laboratory manual for the examination and processing of human semen" [3]. Unfortunately, the manual does not provide exact definitions of each sperm morphology abnormality but photos of some sperm defects are presented only. Consequently, additional criteria for definitions of each sperm defects category were used to standardize sperm morphology classification in our study.

A total of 14 types of anomalies were taken into account.

1. Amorphous head. Amorphous heads include heads vastly misshaped, with irregular edges, asymmetric, with an expanded postacrosomal zone, but not referred to pear-shaped or elongated heads.

2. Pyriform head. This type includes heads with elongated and narrowed postacrosomal zone [2]. The ratio of head length / width was $\geq 2$, with width being measured at equatorial zone [43].

3. Elongated head. The head has length / width ratio >2 [43], but unlike pyriform head width of acrosome and postacrosome zone are the same.

4. Round head. The head has length $/$ width ratio $=1$ [43].

5. 5. Acrosome defect. The acrosome is less than $40 \%$ or greater than $70 \%$ of the head area [3].

6. Vacuolated head. The head has more than two vacuoles, vacuoles occupying more than $20 \%$ of the head area or the located in postacrosomal region [3].

7. Thick midpiece. The midpiece width is more than one mkm [3].

8. Thin midpiece. A width of the midpiece is less than the principal piece width [43].

9. Bent neck. A midpiece forms an angle of $90^{\circ}$ (or less) to the long axis of the sperm head [43].

10. Excessive residual cytoplasm (ERC). The large (more than $1 / 3$ of the head area) cytoplasmic remnant is presented [3].

11. Asymmetrical insertion neck. The attachment of the midpiece is not aligned with central axis of the head [3].

12. Coiled tail. The tail is coiled itself $\left(>360^{\circ}\right)$ [3].

13. Short tail. The tail length is less than $45 \mathrm{mkm}$ [3].

Defects in each spermatozoon were recorded using laboratory counter in multiple-entry system. A percentage of each sperm abnormality and teratozoospermia index (TZI) was calculated according "WHO laboratory manual..." (2010)[3]. 
Statistical analysis. The statistical analysis of the obtained data was performed using the statistical package "Statistica" (version 8.0). The results are presented as mean and its standard deviation and median with 5th - 95th percentiles. The Kolmogorov-Smirnov test was used to determine normality of distribution. Sperm quality parameters and percentages of sperm morphological defects were not normally distributed. The data were best transformed by square root transformation for sperm count and sperm concentration; log transformation for TZI and arcsine transformation for percentages of progressively motile spermatozoa, morphologically normal spermatozoa and percentages of all sperm morphology defects. Descriptive statistics in the tables and the text are presented using untransformed data. Spearman's correlation coefficients were used to determine correlations among all studied parameters. To investigate influences of ethnicity and semen quality on the percentages of sperm morphology defects two-way analysis of variance (ANOVA) was used. Categorical predictors (factors) in ANOVA were ethnos and semen quality status (SQS). Duncan's test was used to determine statistical significance between groups. A p value $<.05$ was regarded as statistically significant.

\section{Results}

\section{Anthropometrical and sociodemographic characteristic}

The Buryats $(n=195)$, the Slavs $(n=89)$ and the Yakuts were included in the study.

Anthropometrical socio-demographic characteristic of the group under study are summarized in Table 1.

\section{Semen quality.}

Two-way ANOVA showed significant influence ethnos and sperm quality status on sperm motility and sperm concentration but there are no ethnos influence on sperm count. The results of ANOVA are presented in the Supplementary Table 1. The men of the Yakut ethnicity had lower sperm concentration in comparison with the Buryats and the Slavs but significant differences in sperm concentration between the Buryats and the Slavs were not revealed. The men of the Yakut and the Slavs ethnicity were characterized by lower sperm motility in comparison with the Buryats (Table 2).

\section{Sperm morphological defects diversity in population}

Among the morphological defects of spermatozoa in the studied population the anomalies of the head (46.16 $\pm 8.65 \%)$, combined defects of head and midpiece $(26.68 \pm 6.81 \%)$, as well as head and tail $(10.45 \pm 5.83 \%)$ were most common. Midpiece $(4.71 \pm 2.82 \%)$ and tail $(1.72 \pm 1.61 \%)$ defects and their combination $(0.51 \pm 0.62 \%)$ as well as the combined defects in all three spermatozoon compartments $(3.66 \pm 2.60 \%)$ were rarely.

Amorphous (62.25 $\pm 12.18 \%)$, elongated $(10.61 \pm 8.62 \%)$, pyriform $(8.61 \pm 9.17 \%)$, and vacuolated heads $(10.31 \pm 6.77 \%)$ as well as abnormal acrosomes $(20.43 \pm 12.67 \%)$ were most frequent among the head defects. Among the midpiece defects follows category predominated: asymmetrical insertion neck (18.33 $\pm 6.43 \%)$, thick midpiece $(6.21 \pm 3.41 \%)$ and bent head $(5.94 \pm 4.02 \%)$. Among the principal piece defects, coiled tail $(10.8 \pm 6.79 \%)$ and short tail $(4.3 \pm 3.26 \%)$ are prevailed. Percentages of several sperm defects such us large, small, double heads and thin midpiece were less than one percent (data not shown).

Two-way ANOVA showed significant influence of ethnos and sperm quality status on percentage of normal sperm and all sperm morphological defects as well as TZI. Moreover, interaction ethnos and SQS was established for TZI only. The results of ANOVA are presented in the Supplementary Table 1.

The subject of the Slav and the Yakut ethnicity (Table 2) had higher TZI, the proportion of pyriform, elongated, vacuolated heads, abnormal acrosome, bent head, asymmetrical tail insertion and ERC as well as the lower proportion of normal sperm and sperm with amorphous head as well as thick midpiece in comparison with the Buryats.

The subject with astenozoospermia and oligoastenozoospermia (Table 3) were characterized by more higher TZI, the proportion of pyriform, elongated heads, abnormal acrosome, bent head, asymmetrical tail insertion and ERC, coiled and short tail as well as the lower proportion of normal sperm and sperm with amorphous head in comparison with normozoospermic men. 
Moreover, the men with oligozoospermia had higher TZI, percentage of combined defects in all three compartments of spermatozoon and lower proportion of normal sperm in comparison with subjects suffered from astenozoospermia.

It should be noted that two-way ANOVA showed interaction between factors "Ethnos" and "SQS" for TZI $\left(F_{4,405}=2.40, p<0.05\right)$. Men of the Buryat ethnicity with oligoastenozoospermia were characterized by higher TZI $(p<0.01)$ compared to the Buryats with normozospermia and astenozoospermia. Moreover TZI in the Buryats with astenozoospermia was higher than in the Buryats with normozospermia $(p<0.01)$. However, there are no significant differences for TZI between the Yakuts and the Slavs with astenozoospermia and oligoastenozoospermia Moreover, there are no significant differences for percentage of normal sperm between the Yakuts with astenozoospermia and oligoastenozoospermia.

Sperm concentration negatively correlated with TZI $(-0.43, p<0.01)$, percentages of acrosome defects $(-0.31, p<0.01)$, bent head $(-0.29, p<0.01)$ and short tail $(-0.38, p<0.01)$. Significant relationships were shown between progressive sperm motility and TZI $(-0.57, p<0.01)$ proportion of normal sperm $(0.64, p<0.01)$, elongated head $(-0.17, p<0.01)$, acrosome defects $(-0.37, p<0.01)$, bent head $(-0.39, p<0.01)$, ERC $(-0.17, p<0.01)$, coiled $(-0.33, p<0.01)$ and short $(-0.41, p<0.01)$ tail.

Percentage of pyriform head positively correlated with elongated $(0.61, p<0.01)$, vacuolated $(0.28, p<0.01)$ head, bent head $(0.35$, $p<0.01)$ and $\operatorname{ERC}(0.34, p<0.01)$.

Percentage of acrosome defect positively correlated with elongated $(0.23, p<0.01)$ round $(0.30, p<0.01)$ and small head $(0.22$, $p<0.01)$. Percentage of bent head was positively correlated with elongated head $(0.30, p<0.01)$ and ERC $(0.30, p<0.01)$.

More information on the correlation among semen quality parameters and percentages of sperm morphology defects is provided in the Supplementary Table 3.

\section{Discussion}

The performed study revealed significant ethnic variability in semen quality and sperm morphology in men from general population located in Eastern Siberia. In comparison with the Slavs and the Yakuts, men of the Buryat ethnicity are characterized by higher progressive sperm motility, percentage of normal sperm and lower TZI. The obtained data suggest better spermiogenesis efficiency in the Buryat compared to the Slavs and the Yakuts. Moreover, the Slavs and the Yakuts are characterized by increased incidence of elongated, pyriform, head, ERC, bent head, asymmetrucal neck insertion, coiled and short tails. To our knowledge the present study is the first one revealing ethnic variation in the percentages of sperm morphological defects. The number of studies performed in USA showed race differences in sperm concentration, sperm motility, as well as rate of oligozoospermia, asthenozoospermia in the population. The Asians had higher mean semen concentrations in comparison with White men [35,36]. Black men with proven fertility had lower semen volume, sperm concentration and total motile sperm counts than White and Hispanic/Latino men [44]. Sperm concentration was significantly higher in men with both parents born in Latvia, compared with men with both parents born outside Latvia [37]. However, ethnic differences in incidence of sperm morholological defects were not studied, although influence of geographic factor on percentages of sperm morphology defects [4] and percentage of morphologically normal sperm [26,29,30] was established. Our study supplements this data and suggests that ethnicity can affect sperm morphogenesis. The reasons of ethnic differences in sperm morphology is unknown but it is possible that ethnic features in spermatogenesis parameters including sperm morphological pattern are caused by genetic background and/or ethnic features of lifestyle - dietary habits, availability of medical care etc. [35].

The Buryats being indigenous group in the Baikal region are typical representatives of the Central Asian anthropological type of the Mongoloids [45]. The Yakuts (also known as Sakha) are a Turkic-speaking population settled over a wide territory of northeastern Siberia in the autonomous Republic Sakha (Yakutia) within the Russian Federation. The evidence from analysis of autosomal SNPs [46] and mtDNA suggest close affinity of the Yakuts with Central Asian and South Siberian groups including the Buryats. The genetic, archaeological, ethnographic and linguistic evidence suggest that the Yakuts migrated north from their original area of settlement around of Lake Baykal in South Siberia along River Lena [47]. However, despite relative genetic affinity of the Yakuts and the Buryats there are severe differences between these ethnic groups in semen quality and sperm 
morphology especially for incidence pyriform and elongated heads. Moreover, the Yakuts are characterized by lower percentage of morphologically normal sperm in comparison with the Buryats and the Slavs as well as other European [33], Asian [30] populations including it from northern regions $[42,48]$. A sperm head elongation is considered to be a stress-induced defect [2] and may result from the influence of any negative external factors affecting testis. Poor sperm morphology in the Yakyts being residents of Yakutsk city may be caused negative effects of severe climatic conditions in this region, where average temperature in January is $-38.6^{\circ} \mathrm{C}$. Yakutsk city $\left(62^{\circ} 01^{\prime} 38^{\prime \prime} \mathrm{N}, 129^{\circ} 43^{\prime} 55^{\prime \prime} \mathrm{E}\right)$ is located in the circumpolar area including territory north of $55^{\circ} \mathrm{N}$ [49]. The circumpolar populations are exposed by the unique complex of adverse environmental factors such as low air temperature, marked seasonality, and peculiar photoperiod with very low day-light hours in winter and elevated ones in summer. These adverse conditions, especially contrast photoperiod, can vastly affect male fertility since the spermatogenesis is known to be susceptible to environmental factors including a length of light day [50,51]. It was revealed that the circumpolar populations are characterized by elevated basal metabolic rate [52]; hyperactivity of the thyroid gland, increased fatty acid metabolism [53], with both functional and genetic factors contributing to metabolic adaptation to the northern conditions [52]. Furthermore climatic or any other environmental factors could influence sperm morphology in the Slavs settling the territory of the Eastern Siberia mostly from the 17th century.

However, ethnic differences between the Buryats and the Yakuts may be also caused by genetic reasons. It was shown by studies of Y-chromosomal short tandem repeats (Y-chromosomal STR) that the Yakuts are characterized by low genetic diversity in Y-chromosomal loci. This fact is considered to be caused by strong reduction in a male population size of Yakuts and existence population bottleneck during their migration in the historical past $[47,54,55]$. In this scenario it is possible that the Yakut population is characterized by increased incidence any genetic variants associated with impaired spermoigenesis due to founder effect.

The present study showed that impaired progressive sperm motility and concentration associated with decreased percentage of sperm with normal morphology and increased proportion most of sperm morphology defects. Wherein lowered motility was associated with percentages sperm morphology defects regardless ethnicity. The relationships between sperm morphology and sperm motility were shown in other studies $[18,19]$. These evidences suggest several common mechanisms resulting in impaired sperm concentration, motility and morphology.

Furthermore the men with oligoastenozoospermia are characterized by vastly decreased proportion of morphologically normal sperm and increased TZI. In our study increasing TZI in men with oligoastenozoospermia compared to men with astenozoospermiawas revealed for the Buryats only, suggesting ethnic features in the relationships between TZI and concentration. Oligozoospermia can result from the number of external and internal reasons - androgen deficiency, chromosomal disorders and genetic mutations, hypogonadotropic hypogonadism, systemic illness, effects of drugs and environmental toxins, partial obstruction of the seminal path and other [56], which can affect spermiogenesis differently in men depending on ethnicity. However, the reasons of this phenomenon are unknown and it should be investigated.

It should be noted that ethnic variability in the percentages of pyriform, elongated head, asymmetrical tail insertion and ERC was coordinated. Significant correlations between percentages elongated and pyriform head, pyriform head and ERC, pyriform head and bent head were revealed. Pyriform head is known to be a common sperm defect and associated with the presence of ERC and midpiece abnormalities It was assumed that elongation of postacrosomal zone of sperm head and head-tail attachment defect result from a disruption of common for head and tail formation but unknown mechanisms of spermiogenesis $[2,57]$. The increased percentage of elongated heads was observed in varicocele [11, 12], severe psychological stress [58], diabetes mellitus with poor diabetic control [51], during experimental scrotal hyperthermia [59]. At the ultrastructural level elongated and pyriform heads are characterized by a excessive nuclear elongation, a presence additional membranous layers between the outer and inner leaves of the nuclear envelope as well as a poorly condensed chromatin $[2,4,11]$. The several mechanismsare considered to underlie elongation of spermatid nucleus and shaping sperm head. Firstly, developing acrosome is surrounded by ectoplasmic specializations of Sertoli cells. Ectoplasmic specializations are formed by a layer of actin bundles and this structure reduces its diameter, exerting external forces to compact the spermatid nucleus. Secondly, the acroplaxome, a cytoskeletal plate composed of F-actin, keratin 5 modulates the exogenous forces generated by Sertoli cells. Moreover, the marginal ring of the acroplaxome and the perinuclear ring of the manchette reduce their diameter as they 
gradually descend along the nucleus toward the spermatid tail in a zipper-like movement that facilitates nuclear condensation and shaping $[60,61]$. Microtubules of manchette participate in intramanchette transport of proteins involved in spermatid development and removing residual cytoplasm [62]. In addition to the cytoskeletal structures, the number of signal and transport proteins is involved in sperm head morphogenesis [61]. In particular, a depletion of genes encoding microtubulerelated proteins such us KIF3A, IFT88, Katanin 80, CEP131, CLIP170 and H00K1 results in anexcessivemanchette elongation and narrowing sperm head as revealed in the studies using knockout mice [62]. This appearance of mice sperm head is similar to pyriform and elongated sperm head in human. These findings suggest that environmental, lifestyle and genetic factors affecting studied population can influence function of several proteins associated with manchette, resulting in formation of pyriform and elongated head and disturbance of spermatid cytoplasm removal and tail formation. It should be noted that this hypothesis needs experimental verification and spermiogenesis disturbance may be caused by other mechanism, which is not understood.

\section{Conclusions}

To conclude the performed study showed significant coordinated ethnic variability in percentage of several sperm morphological defects in men from general population located in the Eastern Siberia. The Buryats had higher sperm quality and lower TZI and proportion of sperm with head elongation and midpiece defects compared with the Slavs and the Yakuts.

Lowered sperm motility was associated with percentages of most sperm abnormalities but ethnic features in the relationships between sperm TZI and sperm concentration was revealed. These findings suggest complex influence environmental or/and genetic factors on molecular processes of sperm head formation and reveal need for consideration of ethnicity in assessing sperm morphology as well as further research on mechanisms of spermiogenesis distribution.

\section{List Of Abbreviations}

TZI teratozoospermia index

SQS - sperm quality status

ANOVA - analysis of variance

ERC - excessive residual cytoplasm

\section{Declarations}

\section{Ethics approval and consent to participate}

The ethics committee of the Federal Research Center 'Institute of Cytology and Genetics', the Siberian Branch of the Russian Academy of Sciences approved the study.

\section{Availability of data and materials}

The datasets used and analyzed during the current study are available from the corresponding author on reasonable request.

\section{Competing interests}

The authors declare that there are no conflicts of interest.

\section{Study funding.}

The study supervision, the data analysis and manuscript writing were supported by project nr19-15-00075 from the Russian Science Foundation. The data compilation was supported by project \#0324-2019-0041 from the Russian Government Budget.

\section{Authors' contributions}


LO: Provided overall supervision of the project, collected questionnaires and samples, interpreted the data; MK and AO: Organized and carried out the experiments, performed the semen and statistical analysis, participated in drafting the manuscript; LS and IT: Organized and carried out the experiments, involved in recruiting young males from the general population. All authors read and approved the manuscript.

\section{Acknowledgements}

We thank physicians Andrei Erkovich, Natalia Voroschilova, Natalia Kuznezova, Bair Daschiev and Vasily Ostobunaev for coordinating the recruitment and performing a physical examination of participants, Ms. Natalia Gutorova for help in collection of questionnaires. All the volunteers participating in the study are thanked.

\section{References}

1. Gatimel N, Moreau J, Parinaud J, Léandri RD. Sperm morphology: assessment, pathophysiology, clinical relevance, and state of the art in 2017. Andrology. 2017;5(5):845-62. doi:10.1111/andr.12389.

2. Menkveld R, Holleboom CA, Rhemrev JP. Measurement and significance of sperm morphology. Asian J Androl. 2011;13(1):59-68. doi:10.1038/aja.2010.67.

3. World Health Organization (WHO) laboratory manual for the examination and processing of human semen 5 th edn. Cambrige University Press 2010.

4. Auger J. Assessing human sperm morphology: top models, underdogs or biometrics? Asian J Androl. 2010;12(1):36-46. doi:10.1038/aja.2009.8.

5. Blom E. The ultrastructure of some characteristic sperm defects and a proposal for a new classification of the bull spermiogram. Nord Vet Med. 1973;25(7):383-391. In Danish

6. Auger J, Jouannet P, Eustache F. Another look at human sperm morphology. Hum Reprod. 2016;31(1):10-23. doi:10.1093/humrep/dev251

7. Chemes HE., Rawe VY. The making of abnormal spermatozoa: cellular and molecular mechanisms underlying pathological spermiogenesis. Cell Tissue Res. 2010; 341(3):349-357. doi: 10.1007/s00441-010-1007-3.

8. Chemes HE, Alvarez Sedo C. Tales of the tail and sperm head aches: changing concepts on the prognostic significance of sperm pathologies affecting the head, neck and tail. Asian J Androl. 2012; 14(1):14-23. doi:10.1038/aja.2011.168.

9. Ray PF, Toure A, Metzler-Guillemain C, Mitchell MJ, Arnoult C, Coutton C. Genetic abnormalities leading to qualitative defects of sperm morphology or function. Clin Genet. 2017;91(2):217-232. doi:10.1111/cge.12905.

10. De Braekeleer M, Nguyen MH, Morel F, Perrin A. Genetic aspects of monomorphic teratozoospermia: a review. J Assist Reprod Genet. 2015;32(4):615-623. doi:10.1007/s10815-015-0433-2.

11. Prisant N, Escalier D, Soufir JC et al. Ultrastructural nuclear defects and increased chromosome aneuploidies in spermatozoa with elongated heads. Hum Reprod. 2007;22(4):1052-1059. doi:10.1093/humrep/del481

12. Prasivoravong J, Marcelli F, Lemaître L, et al. Beneficial effects of varicocele embolization on semen parameters. Basic Clin Androl. 2014;24:9. doi:10.1186/2051-4190-24-9.

13. Elshal MF, El-Sayed IH, Elsaied MA, El-Masry SA, Kumosani TA. Sperm head defects and disturbances in spermatozoa chromatin and DNA integrities in idiopathic infertile subjects: association with cigarette smoking. ClinBiochem. 2009;42(78):589-594. doi:10.1016/j.clinbiochem.2008.11.012

14. Mangiarini A, Paffoni A, Restelli L, et al. Specific sperm defects are differentially correlated with DNA fragmentation in both normozoospermic and teratozoospermic subjects. Andrology. 2013;1(6):838-844. doi:10.1111/j.2047-2927.2013.00138.x.

15. Oumaima A, Tesnim A, Zohra H, et al. Investigation on the origin of sperm morphological defects: oxidative attacks, chromatin immaturity, and DNA fragmentation. Environ Sci Pollut Res Int. 2018;25(14):13775-13786. doi:10.1007/s11356018-1417-4.

16. Gandini L, Lombardo F, Paoli D, et al. Study of apoptotic DNA fragmentation in human spermatozoa. Hum Reprod. 2000;15(4):830-839. doi:10.1093/humrep/15.4.830.

Page $10 / 17$ 
17. Chelli MH, Albert M, Ray PF, et al. Can intracytoplasmic morphologically selected sperm injection be used to select normalsized sperm heads in infertile patients with macrocephalic sperm head syndrome? Fertil Steril. 2010;93(4):1347.e1-

1347.e13475. doi:10.1016/j.fertnstert.2008.10.059

18. Parinaud J, Vieitez G, Moutaffian H et al., Relationships between motility parameters, morphology and acrosomal status of human spermatozoa. Hum Reprod. 1996;11(6):1240-3. doi: 10.1093/oxfordjournals.humrep.a019364.

19. Piasecka M, Laszczyńska M, Gaczarzewicz D. Morphological and functional evaluation of spermatozoa from patients with asthenoteratozoospermia. Folia Morphol (Warsz). 2003; 62(4):479-81.

20. Boitrelle F, Pagnier M, Athiel Y, et al. A human morphologically normal spermatozoon may have noncondensed chromatin. Andrologia. 2015;47(8):879-886. doi:10.1111/and.12341.

21. Evgeni E, Charalabopoulos K, Asimakopoulos B. Human sperm DNA fragmentation and its correlation with conventional semen parameters. J Reprod Infertil. 2014;15(1):2-14.

22. Curchoe CL, Bormann CL. Artificial intelligence and machine learning for human reproduction and embryology presented at ASRM and ESHRE 2018. J Assist Reprod Genet. 2019;36(4):591-600. doi:10.1007/s10815-019-01408-x.

23. Iqbal I, Mustafa G, Ma J. Deep learning-based morphological classification of human sperm heads. Diagnostics (Basel). 2020;10(5):325. doi:10.3390/diagnostics10050325.

24. Auger J, Eustache F, Andersen AG, et al. Sperm morphological defects related to environment, lifestyle and medical history of 1001 male partners of pregnant women from four European cities. Hum Reprod. 2001;16(12):2710-2717. doi:10.1093/humrep/16.12.2710.

25. Jørgensen N, Andersen AG, Eustache F, et al. Regional differences in semen quality in Europe. Hum Reprod. 2001;16(5):1012-1019. doi:10.1093/humrep/16.5.1012.

26. Punab M, Zilaitiene B, Jørgensen N, et al. Regional differences in semen qualities in the Baltic region. Int J Androl. 2002;25(4):243-252. doi:10.1046/j.1365-2605.2002.00359.x.

27. Swan SH, Brazil C, Drobnis EZ, et al. Geographic differences in semen quality of fertile U.S. males. Environ Health Perspect. 2003;111(4):414-420. doi:10.1289/ehp.5927.

28. Li WN, Jia MM, Peng YQ, Ding R, Fan LQ, Liu G. Semen quality pattern and age threshold: a retrospective cross-sectional study of 71,623 infertile men in China, between 2011 and 2017. Reprod Biol Endocrinol. 2019;17(1):107. doi:10.1186/s12958-019-0551-2.

29. Erenpreiss J, Punab M, Zilaitiene B, et al. Semen quality of young men from the general population in Baltic countries. Hum Reprod. 2017;32(6):1334-1340. doi:10.1093/humrep/dex062.

30. Iwamoto T, Nozawa S, Mieno MN, et al. Semen quality of 1559 young men from four cities in Japan: a cross-sectional population-based study. BMJ Open. 2013;3(4):e002222. doi:10.1136/bmjopen-2012-002222.

31. Carlsen E, Giwercman A., Keiding N., Skakkebaek NE. Evidence for decreasing quality of semen during past 50 years.BMJ.1992; 305(6854): 609-613. doi: 10.1136/bmj.305.6854.609

32. Rolland M, Le Moal J, Wagner V, Royère $D$, De Mouzon J. Decline in semen concentration and morphology in a sample of 26,609 men close to general population between 1989 and 2005 in France. Hum Reprod. 2013;28(2):462-470. doi:10.1093/humrep/des415.

33. Jørgensen N, Joensen UN, Jensen TK, et al. Human semen quality in the new millennium: a prospective cross-sectional population-based study of 4867 men. BMJ Open. 2012;2(4):e000990. doi:10.1136/bmjopen-2012-000990

34. Skakkebaek NE, Rajpert-De Meyts E, Buck Louis GM, et al. Male reproductive disorders and fertility trends: influences of environment and genetic susceptibility. Physiol Rev. 2016;96(1):55-97. doi:10.1152/physrev.00017.2015

35. Glazer CH, Li S, Zhang CA, Giwercman A, Bonde JP, Eisenberg ML. Racial and sociodemographic differences of semen parameters among US men undergoing a semen analysis. Urology. 2019;123:126-132. doi:10.1016/j.urology.2018.09.029.

36. Khandwala YS, Zhang CA, Li S, Behr B, Guo D, Eisenberg ML. Racial variation in semen quality at fertility evaluation. Urology. 2017;106:96-102. doi:10.1016/j.urology.2017.03.064. 
37. Tsarev I, Gagonin V, Giwercman A, Erenpreiss J. Sperm concentration in Latvian military conscripts as compared with other countries in the Nordic-Baltic area. Int J Androl. 2005;28(4):208-214. doi:10.1111/j.1365-2605.2005.00523.x.

38. Humphries LA, Chang O, Humm K. et al., Influence of race and ethnicity on in vitro fertilization outcomes: systematic review. Am J Obstet Gynecol. 2016 ;214(2): 212.e1-212.e17. doi: 10.1016/j.ajog.2015.09.002.

39. Kaneshiro B, Geling O, Gellert K, Millar L. The challenges of collecting data on race and ethnicity in a diverse, multiethnic state. Hawaii Med J. 2011;70(8):168-71.

40. Osadchuk LV, Kleshchev MA, Gutorova NV, et al. Regional peculiarities in semen quality and serum hormonal concentrations of citizens from Eastern Siberia. Vestn Ross Akad Med Nauk. 2012;(3):50-55. In Russ

41. Gutorova NV, Kleshchyov MA, Tipisova EV, Osadchuk LV. Effects of overweight and obesity on the spermogram values and levels of reproductive hormones in the male population of the European north of Russia. Bull Exp Biol Med. 2014;157(1):9598. doi:10.1007/s10517-014-2500-6.

42. Osadchuk L, Tipisova E, Kleshchev M, Gorenko I, Osadchuk A. Study of semen quality, reproductive hormone levels, and lipid levels in men from Arkhangelsk, a city in North of European Russia. Am J Mens Health. 2020 14(4):1557988320939714. doi: 10.1177/1557988320939714.

43. Rothmann SA, Bort AM, Quigley J, Pillow R. Sperm morphology classification: a rational method for schemes adopted by the World Health Organization. Methods Mol Biol. 2013;927:27-37. doi:10.1007/978-1-62703-038-0_4.

44. Redmon JB, Thomas W, Ma W, et al. Semen parameters in fertile US men: the Study for Future Families. Andrology. 2013;1(6):806-814. doi:10.1111/j.2047-2927.2013.00125.x.

45. Derenko M, Denisova G, Malyarchuk B, Dambueva I, BazarovB. Mitogenomic diversity and differentiation of the Buryats. J Hum Genet. 2018;63(1):71-81. doi:10.1038/s10038-017-0370-2.

46. Zlobin A.S., Sharapov S.S., Guryev VP. et al., Population specific analysis of Yakut exomes. Dokl Biochem Biophys. 2017;474(1):213-216. doi: 10.1134/S1607672917030188. Epub 2017 Jul 20. PMID: 28726087.

47. Pakendorf B, Novgorodov IN, Osakovskij VL, et al. Investigating the effects of prehistoric migrations in Siberia: genetic variation and the origins of Yakuts. Hum Genet. 2006;120(3):334-53. doi: 10.1007/s00439-006-0213-2.

48. Halling J, Petersen MS, Jørgensen N, Jensen TK, Grandjean P, Weihe P. Semen quality and reproductive hormones in Faroese men: a cross-sectional population-based study of 481 men. BMJ Open. 2013; 3(3): e001946. doi: 10.1136/bmjopen-2012-001946.

49. Snodgrass J, Sorensen MV, Tarskaia LA, Leonard WR. Adaptive dimensions of health research among indigenous Siberians. Am J Hum Biol 2007; 19: 165-80.

50. Mao H, Feng L, Yang WX. Environmental factors contributed to circannual rhythm of semen quality. Chronobiol Int. 2017; 34: 411-25.

51. Omu AE. Sperm parameters: paradigmatic index of good health and longevity. Med Princ Pract. 2013; 22 Suppl 1: 30-42.

52. Leonard WR, Sorensen MV, Galloway VA, Spencer GJ, Mosher MJ et al. Climatic influences on basal metabolic rates among circumpolar populations. Am J Hum Biol. 2002; 14: 609-20.

53. Itoh S. Physiology of circumpolar people. In: Milan, M. editor. The Human Biology of Circumpolar Populations.Cambridge University Press; 1980. p. 285-305.

54. Pakendorf B, Morar B, Tarskaia LA et al., Y-chromosomal evidence for a strong reduction in male population size of Yakuts. Hum Genet. 2002;110(2):198-200. doi: 10.1007/s00439-001-0664-4.

55. Keyser C, Hollard C, Gonzalez A et al., The ancient Yakuts: a population genetic enigma. Philos Trans R Soc Lond B Biol Sci. 2015; 370(1660):20130385. doi: 10.1098/rstb.2013.0385.

56. McLachlan RI. Approach to the patient with oligozoospermia. J Clin Endocrinol Metab. 2013; 98(3): 873-80. doi: 10.1210/jc.2012-3650.

57. Rousso D, Kourtis A, Mavromatidis G, Gkoutzioulis F, Makedos G, Panidis D. Pyriform head: a frequent but little-studied morphological abnormality of sperm. Arch Androl. 2002;48(4):267-272. doi:10.1080/01485010290031574.

Page $12 / 17$ 
58. Fenster L, Katz DF, Wyrobek AJ, et al. Effects of psychological stress on human semen quality. J Androl. 1997;18(2):194202.

59. Mieusset R, Bujan L, Mansat A, Pontonnier F, Grandjean H. Effects of artificial cryptorchidism on sperm morphology. Fertil Steril. 1987;47(1):150-155.

60. Teves ME, Roldan ERS, Krapf D, Strauss JF et al.. Sperm differentiation: the role of trafficking of proteins. Int J Mol Sci. 2020 May 24;21(10):3702.

61. Kierszenbaum AL., Rivkin E, Tres L. Molecular biology of sperm head shaping. Soc Reprod Fertil 2007; 65: Suppl:33-43.

62. Lehti MS, Sironen A. Formation and function of the manchette and flagellum during spermatogenesis. Reproduction. 2016;151(4):R43-R54. doi:10.1530/REP-15-0310.

\section{Tables}

Table 1. Demographic and anthropometric characteristics in men of different ethnic groups.

\begin{tabular}{|c|c|c|c|c|c|c|}
\hline & \multicolumn{2}{|c|}{ Buryats $(n=195)$} & \multicolumn{2}{|l|}{ Slavs $(n=89)$} & \multicolumn{2}{|c|}{ Yakuts $(n=130)$} \\
\hline & Mean(SD) & Median(5-95) & Mean(SD) & Median(5-95) & Mean(SD) & Median(5-95) \\
\hline Age, year & $23.9(6.4)$ & $21.0(18.0-37.0)$ & $24.0(5.8)$ & $23.0(18.0-34.0)$ & $25.3(6.8)$ & $23.0(18.0-39.0)$ \\
\hline $\begin{array}{l}\text { Body } \\
\text { weight,kg }\end{array}$ & $70.7(13.3)^{a}$ & $67.5(54.0-94.0)$ & $\begin{array}{l}76.0 \\
(14.0)^{a b}\end{array}$ & $72.0(58.0-101.5)$ & $71.0(14.1)^{b}$ & $68.5(54.0-99.0)$ \\
\hline Height, cm & $174.8(6.4)^{\mathrm{ac}}$ & $\begin{array}{l}174.0(165.0- \\
186.0)\end{array}$ & $\begin{array}{l}178.4 \\
(6.3)^{a b}\end{array}$ & $\begin{array}{l}\text { 179.0(169.0- } \\
190.0)\end{array}$ & $172.4(6.3)^{b c}$ & $\begin{array}{l}172.0(162.0- \\
182.0)\end{array}$ \\
\hline BTV, ml & $35.8(7.0)^{a}$ & $40.0(24.0-50.0)$ & $42.4(7.3)^{\mathrm{ab}}$ & 40.7 (32.6-50.0) & $36.3(8.4)^{b}$ & $36.0(28.0-50.0)$ \\
\hline $\begin{array}{l}\text { Abstinence, } \\
\text { day }\end{array}$ & $4.3(5.9)$ & $3.0(1.50-14.0)$ & $3.4(3.7)$ & $3.0(1.0-6.0)$ & $3.4(3.0)$ & $3.0(1.0-7.0)$ \\
\hline
\end{tabular}

Note. SD - standard deviation; (5-95) - 5th-95th percentile, BTV - bitesticular volume.

Table 2. Sperm quality and sperm morphology defects in men of different ethnic groups. 


\begin{tabular}{|c|c|c|c|c|c|c|}
\hline \multirow[t]{2}{*}{ Parameters } & \multicolumn{2}{|l|}{ Buryats(n=195) } & \multicolumn{2}{|l|}{ Slavs $(n=89)$} & \multicolumn{2}{|l|}{ Yakuts $(n=130)$} \\
\hline & Mean(SD) & $\begin{array}{l}\text { Median(5- } \\
95)\end{array}$ & Mean(SD) & $\begin{array}{l}\text { Median(5- } \\
95)\end{array}$ & Mean(SD) & $\begin{array}{l}\text { Median(5- } \\
95)\end{array}$ \\
\hline \multicolumn{7}{|l|}{ Semen quality } \\
\hline Sperm count, mln & $113.4(110.8)$ & $\begin{array}{l}74.8(10.2- \\
318.4)\end{array}$ & $115.64(94)$ & $\begin{array}{l}90.3(11.5- \\
297.4)\end{array}$ & 104.2(84.3) & $\begin{array}{l}77.9(11.2- \\
257.1)\end{array}$ \\
\hline $\begin{array}{l}\text { Sperm concentration, } \\
\mathrm{mln} / \mathrm{ml}\end{array}$ & $45.44(35.80)^{c}$ & $\begin{array}{l}37.6(7.5- \\
114.0)\end{array}$ & $42.71(37.24)^{b}$ & $\begin{array}{l}30.62(4.63- \\
137.19)\end{array}$ & $35.4(26.15)^{c b}$ & $\begin{array}{l}31.69(5.50- \\
92.13)\end{array}$ \\
\hline Sperm motility, \% & $46.17(27.62)^{\mathrm{ac}}$ & $\begin{array}{l}44.67(3.23- \\
89.8)\end{array}$ & $37.30(25.45)^{a}$ & $\begin{array}{l}31.87(2.03- \\
87.03)\end{array}$ & $36.79(22.62)^{c}$ & $\begin{array}{l}33.77(6.30- \\
75.13)\end{array}$ \\
\hline Normal sperm, \% & $6.79(2.70)^{a c}$ & $\begin{array}{l}6.75(2.75- \\
11.25)\end{array}$ & $5.36(2.49)^{a b}$ & $\begin{array}{l}5.00(2.00- \\
9.75)\end{array}$ & $4.8(2.35)^{c b}$ & $\begin{array}{l}4.75(1.0- \\
8.50)\end{array}$ \\
\hline TZI & $1.48(0.11)^{\mathrm{ac}}$ & $\begin{array}{l}1.47(1.32- \\
1.68)\end{array}$ & $1.53(0.12)^{a}$ & $\begin{array}{l}1.51(1.35- \\
1.71)\end{array}$ & $1.53(0.12)^{c}$ & $\begin{array}{l}1.52(1.35- \\
1.74)\end{array}$ \\
\hline \multicolumn{7}{|l|}{ Head abnormalities } \\
\hline Amorphous, \% & $66.05(10.18)^{a c}$ & $\begin{array}{l}67.00(45.00- \\
79.00)\end{array}$ & $58.86(12.73)^{a}$ & $\begin{array}{l}61.00(35.00- \\
75.50)\end{array}$ & $58.88(12.95)^{c}$ & $\begin{array}{l}\text { 60.75(35.00- } \\
77.00)\end{array}$ \\
\hline Pyriform, \% & $5.89(6.50)^{\mathrm{ac}}$ & $\begin{array}{l}3.50(0.0- \\
19.50)\end{array}$ & $10.30(9.63)^{a}$ & $\begin{array}{l}7.00(0.50- \\
32.00)\end{array}$ & $11.54(10.97)^{c}$ & $\begin{array}{l}8.76(1.00- \\
35.00)\end{array}$ \\
\hline Elongated, \% & $8.40(7.44)^{\mathrm{ac}}$ & $\begin{array}{l}6.50(0.5- \\
24.00)\end{array}$ & $13.13(9.68)^{a}$ & $\begin{array}{l}12.00(1.00- \\
32.00)\end{array}$ & $12.20(8.74)^{c}$ & $\begin{array}{l}10.50(2.00- \\
30.50)\end{array}$ \\
\hline Round, \% & $3.90(3.87)^{\mathrm{C}}$ & $\begin{array}{l}2.50(0.50- \\
12.00)\end{array}$ & $3.69(3.85)^{b}$ & $\begin{array}{l}2.00(0.50- \\
10.50)\end{array}$ & $2.41(2.31)^{c b}$ & $\begin{array}{l}1.52(0.00- \\
7.32)\end{array}$ \\
\hline Vacuolated, \% & $9.47(6.14)^{c}$ & $\begin{array}{l}8.50(1.50- \\
21.50)\end{array}$ & $10.58(6.79)$ & $\begin{array}{l}9.50(2.50- \\
22.00)\end{array}$ & $11.39(7.52)^{c}$ & $\begin{array}{l}10.00(2.50- \\
24.50)\end{array}$ \\
\hline Abn. acrosome, \% & $18.98(12.11)^{a}$ & $\begin{array}{l}15.50(4.50- \\
43.60)\end{array}$ & $23.01(14.01)^{a}$ & $\begin{array}{l}19.50(8.00- \\
48.75)\end{array}$ & $20.85(12.31)$ & $\begin{array}{l}18.00(6.00- \\
49.50)\end{array}$ \\
\hline \multicolumn{7}{|l|}{ Midpiece abnormalities } \\
\hline Bent head, \% & $4.97(3.62)^{\mathrm{ac}}$ & $\begin{array}{l}4.25(1.25- \\
10.50)\end{array}$ & $5.84(3.3)^{a b}$ & $\begin{array}{l}5.00(1.50- \\
13.00)\end{array}$ & $7.46(4.56)^{b c}$ & $\begin{array}{l}6.50(2.00- \\
16.15)\end{array}$ \\
\hline $\begin{array}{l}\text { Assymetrical } \\
\text { insertion, \% }\end{array}$ & $16.92(6.01)^{\mathrm{ac}}$ & $\begin{array}{l}16.50(7.50- \\
26.50)\end{array}$ & $19.39(5.93)^{\mathrm{a}}$ & $\begin{array}{l}19.00(10.50- \\
30.00)\end{array}$ & $19.74(6.96)^{c}$ & $\begin{array}{l}19.60(9.50- \\
32.00)\end{array}$ \\
\hline Thick, \% & $6.76(3.55)^{d c}$ & $\begin{array}{l}6.00(2.00- \\
13.70)\end{array}$ & $5.80(3.14)^{d}$ & $\begin{array}{l}5.50(2.00- \\
12.50)\end{array}$ & $5.65(3.26)^{c}$ & $\begin{array}{l}5.00(1.15- \\
11.50)\end{array}$ \\
\hline \multicolumn{7}{|l|}{ Tail abnormalities } \\
\hline Double, \% & $1.23(1.15)$ & $\begin{array}{l}1.00(0.00- \\
3.00)\end{array}$ & $1.27(1.26)$ & $\begin{array}{l}1.00(0.00- \\
4.00)\end{array}$ & $1.16(2.04)$ & $\begin{array}{l}1.00(0.00- \\
3.00)\end{array}$ \\
\hline Coiled, \% & $9.47(6.30)^{\mathrm{ac}}$ & $\begin{array}{l}8.00(2.75- \\
22.50)\end{array}$ & $11.48(6.45)^{a}$ & $\begin{array}{l}10.50(3.50- \\
25.50)\end{array}$ & $12.52(7.31)^{c}$ & $\begin{array}{l}10.99(3.50- \\
25.50)\end{array}$ \\
\hline Short, \% & $3.85(2.82)^{d c}$ & $\begin{array}{l}3.25(0.50- \\
10.00)\end{array}$ & $4.77(3.83)^{d}$ & $\begin{array}{l}4.00(0.50- \\
13.50)\end{array}$ & $4.64(3.39)^{c}$ & $\begin{array}{l}3.92(0.50- \\
11.50)\end{array}$ \\
\hline \multicolumn{7}{|c|}{ Excessive residual cytoplasm } \\
\hline ERC, \% & $6.75(3.37)^{\mathrm{dc}}$ & $\begin{array}{l}6.00(2.50- \\
12.50)\end{array}$ & $8.01(4.80)^{b}$ & $\begin{array}{l}7.00(1.50- \\
16.00)\end{array}$ & $8.15(4.62)^{b c}$ & $\begin{array}{l}7.50(2.50- \\
15.00)\end{array}$ \\
\hline Abnormalities in diffe & arts of a spern & ozoon & & & & \\
\hline
\end{tabular}




\begin{tabular}{|c|c|c|c|c|c|c|}
\hline Head, \% & $48.64(8.26)^{\mathrm{ac}}$ & $\begin{array}{l}48.00(35.50- \\
62.00)\end{array}$ & $44.82(8.35)^{a}$ & $\begin{array}{l}45.00(30.50- \\
58.50)\end{array}$ & $43.34(8.39)^{c}$ & $\begin{array}{l}42.50(28.50- \\
59.00)\end{array}$ \\
\hline Midpiece, \% & $4.64(2.71)$ & $\begin{array}{l}4.50(1.00- \\
10.00)\end{array}$ & $4.37(2.73)$ & $\begin{array}{l}4.00(1.00- \\
9.00)\end{array}$ & $5.05(3.01)$ & $\begin{array}{l}5.00(0.71- \\
10.74)\end{array}$ \\
\hline Tail, \% & $1.72(1.63)$ & $\begin{array}{l}1.50(0.00- \\
5.00)\end{array}$ & $1.57(1.39)$ & $\begin{array}{l}1.25(0.00- \\
4.50)\end{array}$ & $1.84(1.73)$ & $\begin{array}{l}1.50(0.00- \\
5.50)\end{array}$ \\
\hline Head\&Midpiece, \% & $25.11(6.22)^{\mathrm{ac}}$ & $\begin{array}{l}25.00(14.00- \\
36.00)\end{array}$ & $27.67(6.27)^{a}$ & $\begin{array}{l}27.50(17.50- \\
38.00)\end{array}$ & $28.37(7.51)^{c}$ & $\begin{array}{l}27.50(16.50- \\
43.50)\end{array}$ \\
\hline Head\&Tail, \% & $9.15(5.24)^{\mathrm{ac}}$ & $\begin{array}{l}8.50(3.00- \\
19.50)\end{array}$ & $11.42(6.07)^{\mathrm{a}}$ & $\begin{array}{l}9.50(4.00- \\
24.00)\end{array}$ & $11.74(6.11)^{c}$ & $\begin{array}{l}10.25(4.50- \\
23.50)\end{array}$ \\
\hline Midpiece\&Tail, \% & $0.46(0.59)$ & $\begin{array}{l}0.50(0.00- \\
1.50)\end{array}$ & $0.50(0.54)$ & $\begin{array}{l}0.50(0.00- \\
1.50)\end{array}$ & $0.60(0.7)$ & $\begin{array}{l}0.50(0.00- \\
2.00)\end{array}$ \\
\hline $\begin{array}{l}\text { Head\&Midpiece\&Tail, } \\
\%\end{array}$ & $3.18(2.38)^{\mathrm{ac}}$ & $\begin{array}{l}3.00(0.50- \\
7.50)\end{array}$ & $4.01(2.67)^{a}$ & $\begin{array}{l}3.50(1.0- \\
9.25)\end{array}$ & $4.14(2.76)^{c}$ & $\begin{array}{l}3.50(1.00- \\
10.00)\end{array}$ \\
\hline
\end{tabular}

Note. SD - standard deviation; (5-95) - 5th-95th percentile.

Same superscripts in different columns denote differences in mean values by Duncan test:

between Buryats and Slavs: a - $p<0.05$

between Slavs and Yakuts: $b-p<0.05$

between Yakuts and Buryats:- $c-p<0.05$

Table 3. Sperm quality and sperm morphology defects in men with different sperm quality. 


\begin{tabular}{|c|c|c|c|c|c|c|}
\hline & \multicolumn{2}{|c|}{$\begin{array}{l}\text { Normozoospermia } \\
\mathrm{n}=239\end{array}$} & \multicolumn{2}{|c|}{$\begin{array}{l}\text { Astenozoospermia } \\
\mathrm{n}=95\end{array}$} & \multicolumn{2}{|c|}{$\begin{array}{l}\text { Oligoastenozoospermia } \\
\mathrm{n}=80\end{array}$} \\
\hline & Mean(SD) & $\begin{array}{l}\text { Median(5- } \\
95)\end{array}$ & Mean(SD) & $\begin{array}{l}\text { Median(5- } \\
95)\end{array}$ & Mean(SD) & $\begin{array}{l}\text { Median(5- } \\
95)\end{array}$ \\
\hline \multicolumn{7}{|l|}{ Semen quality } \\
\hline Sperm count, mln & $153.1(106.1)^{\mathrm{ac}}$ & $\begin{array}{l}130.8(35.5- \\
333.2)\end{array}$ & $75.79(54.25)^{\mathrm{ab}}$ & $\begin{array}{l}63.1(16.7- \\
173.5)\end{array}$ & $27.1(19.4)^{b c}$ & $\begin{array}{l}23.52(2.37- \\
66.97)\end{array}$ \\
\hline $\begin{array}{l}\text { Sperm concentration, } \\
\mathrm{mln} / \mathrm{ml}\end{array}$ & $58.42(34.32)^{\mathrm{ac}}$ & $\begin{array}{l}49(21.13- \\
137.19)\end{array}$ & $27.41(11.41)^{a b}$ & $\begin{array}{l}25.0(15.75- \\
51.62)\end{array}$ & $8.76(3.96)^{b c}$ & $\begin{array}{l}9.25(1.00- \\
14.00)\end{array}$ \\
\hline Sperm motility, \% & $59.41(18.30)^{\mathrm{ac}}$ & $\begin{array}{l}55.83(34.15- \\
91.15)\end{array}$ & $21.43(7.45)^{a b}$ & $\begin{array}{l}22.20(7.60- \\
31.20)\end{array}$ & $10.88(7.72)^{\mathrm{bc}}$ & $\begin{array}{l}9.38(0.76- \\
25.58)\end{array}$ \\
\hline Normal sperm, \% & $7.08(2.41)^{\mathrm{ac}}$ & $\begin{array}{l}6.97(3.5- \\
11.25)\end{array}$ & $4.68(2.21)^{\mathrm{ab}}$ & $\begin{array}{l}4.25(1.25- \\
8.50)\end{array}$ & $3.61(1.85)^{b c}$ & $\begin{array}{l}3.50(0.88- \\
6.94)\end{array}$ \\
\hline TZI & $1.46(0.09)^{a}$ & $\begin{array}{l}1.46(1.31- \\
1.62)\end{array}$ & $1.56(0.1)^{\mathrm{ac}}$ & $\begin{array}{l}1.56(1.40- \\
1.73)\end{array}$ & $1.59(0.13)^{\mathrm{c}}$ & $\begin{array}{l}1.59(1.36- \\
1.8)\end{array}$ \\
\hline \multicolumn{7}{|l|}{ Head abnormalities } \\
\hline Amorphous, \% & $56.40(12.62)^{d c}$ & $\begin{array}{l}58.25(34.00- \\
75.00)\end{array}$ & $52.54(14.67)^{a}$ & $\begin{array}{l}56.50(26.50- \\
71.50)\end{array}$ & $52.26(15.50)^{\mathrm{dc}}$ & $\begin{array}{l}52.25(24- \\
74.71)\end{array}$ \\
\hline Pyriform, \% & $7.30(7.27)^{d c}$ & $\begin{array}{l}5.00(0.25- \\
21.50)\end{array}$ & $9.92(10.89)^{d}$ & $\begin{array}{l}6.00(0.50- \\
35.00)\end{array}$ & $10.98(11.23)^{c}$ & $\begin{array}{l}6.13(0.63- \\
35.85)\end{array}$ \\
\hline Elongated, \% & $9.51(8.05)^{d c}$ & $\begin{array}{l}7.00(0.81- \\
26.00)\end{array}$ & $11.9(9.51)^{d}$ & $\begin{array}{l}9.00(0.76- \\
32.50)\end{array}$ & $12.39(8.77)^{c}$ & $\begin{array}{l}10.73(1.08- \\
30.75)\end{array}$ \\
\hline Round, \% & $3.08(3.30)$ & $\begin{array}{l}2.00(0.50- \\
9.00)\end{array}$ & $3.83(4.04)$ & $\begin{array}{l}2.50(0.00- \\
11.00)\end{array}$ & 3.79(3.37) & $\begin{array}{l}2.50(0.00- \\
10.38)\end{array}$ \\
\hline Vacuolated, \% & $10.16(6.68)$ & $\begin{array}{l}8.50(2.00- \\
21.50)\end{array}$ & $9.86(6.43)$ & $\begin{array}{l}8.50(2.00- \\
22.00)\end{array}$ & $11.29(7.42)$ & $\begin{array}{l}10.13(1.50- \\
27.50)\end{array}$ \\
\hline $\begin{array}{l}\text { Abnormal acrosome, } \\
\%\end{array}$ & $17.84(11.63)^{\mathrm{ac}}$ & $\begin{array}{l}15.00(4.00- \\
42.50)\end{array}$ & $22.67(12.97)^{a}$ & $\begin{array}{l}19.50(9.15- \\
49.50)\end{array}$ & $25.52(13.38)^{c}$ & $\begin{array}{l}21.96(8.50- \\
52.49)\end{array}$ \\
\hline \multicolumn{7}{|l|}{ Midpiece abnormalities } \\
\hline Bent head, \% & $4.84(3.31)^{\mathrm{ac}}$ & $\begin{array}{l}4.00(1.00- \\
10.50)\end{array}$ & $7.03(3.66)^{\mathrm{a}}$ & $\begin{array}{l}6.50(2.50- \\
15.75)\end{array}$ & $7.92(5.14)^{c}$ & $\begin{array}{l}7.00(2.38- \\
16.75)\end{array}$ \\
\hline Assymetry, \% & $17.90(6.55)^{\mathrm{c}}$ & $\begin{array}{l}17.00(8.00- \\
30.00)\end{array}$ & $18.20(6.50)$ & $\begin{array}{l}17.50(9.50- \\
32.39)\end{array}$ & $19.78(5.85)^{\mathrm{c}}$ & $\begin{array}{l}19.50(10.48- \\
29.13)\end{array}$ \\
\hline Thick, \% & $5.90(3.19)^{\mathrm{c}}$ & $\begin{array}{l}5.50(1.50- \\
12.00)\end{array}$ & 6.34(3.39) & $\begin{array}{l}6.00(2.00- \\
13.00)\end{array}$ & $6.95(3.93)^{c}$ & $\begin{array}{l}6.00(1.50- \\
13.35)\end{array}$ \\
\hline \multicolumn{7}{|l|}{ Tail abnormalities } \\
\hline Double, \% & $1.04(0.90)$ & $\begin{array}{l}1.00(0.00- \\
3.00)\end{array}$ & $1.30(1.27)$ & $\begin{array}{l}1.00(0.00- \\
3.50)\end{array}$ & $1.67(2.68)$ & $\begin{array}{l}1.00(0.00- \\
4.30)\end{array}$ \\
\hline Coiled, \% & $9.47(6.47)^{\mathrm{ac}}$ & $\begin{array}{l}7.50(3.00- \\
22.50)\end{array}$ & $12.96(6.26)^{a}$ & $\begin{array}{l}12.00(4.00- \\
25.50)\end{array}$ & $12.51(7.36)^{c}$ & $\begin{array}{l}10.50(3.93- \\
26.50)\end{array}$ \\
\hline Short, \% & $3.39(2.63)^{\mathrm{ac}}$ & $\begin{array}{l}3.00(0.50- \\
8.50)\end{array}$ & $5.03(3.63)^{a b}$ & $\begin{array}{l}4.00(1.00- \\
12.00)\end{array}$ & $6.13(3.56)^{b c}$ & $\begin{array}{l}5.25(1.25- \\
12.69)\end{array}$ \\
\hline \multicolumn{7}{|c|}{ Excessive residual cytoplasm } \\
\hline ERC, \% & $6.74(3.53)^{\mathrm{ac}}$ & $\begin{array}{l}6.00(2.00- \\
14.00)\end{array}$ & $8.49(4.47)^{a}$ & $\begin{array}{l}7.50(3.00- \\
16.00)\end{array}$ & $8.39(5.09)^{c}$ & $\begin{array}{l}7.51(2- \\
19.09)\end{array}$ \\
\hline
\end{tabular}




\begin{tabular}{|c|c|c|c|c|c|c|}
\hline Head, \% & $48.64(8.12)^{a c}$ & $\begin{array}{l}48.50(35.00- \\
61.50)\end{array}$ & $43.57(8.38)^{a}$ & $\begin{array}{l}42.50(29.50- \\
57.50)\end{array}$ & $41.83(7.94)^{c}$ & $\begin{array}{l}41.16(28.16- \\
57.25)\end{array}$ \\
\hline Midpiece, \% & $4.93(2.63)^{\mathrm{a}}$ & $\begin{array}{l}4.50(1.50- \\
10.00)\end{array}$ & $4.43(2.92)$ & $\begin{array}{l}4.00(1.00- \\
10.50)\end{array}$ & $4.40(3.19)^{a}$ & $\begin{array}{l}4.00(0.50- \\
10.42)\end{array}$ \\
\hline Tail, \% & $1.67(1.54)$ & $\begin{array}{l}1.50(0.00- \\
5.00)\end{array}$ & $1.76(1.51)$ & $\begin{array}{l}1.50(0.00- \\
5.00)\end{array}$ & $1.82(1.93)$ & $\begin{array}{l}1.25(0.00- \\
6.49)\end{array}$ \\
\hline Head\&Midpiece, \% & $25.18(6.39)^{a c}$ & $\begin{array}{l}25.00(14.50- \\
36.00)\end{array}$ & $28.00(6.33)^{a}$ & $\begin{array}{l}27.50(17.50- \\
39.44)\end{array}$ & $29.61(7.39)^{c}$ & $\begin{array}{l}29.02(18.00- \\
44.56)\end{array}$ \\
\hline Head\&Tail, \% & $9.00(5.31)^{\mathrm{ac}}$ & $\begin{array}{l}8.00(3.00- \\
19.50)\end{array}$ & $12.62(5.87)^{\mathrm{a}}$ & $\begin{array}{l}12.00(5.00- \\
24.25)\end{array}$ & $12.22(6.02)^{c}$ & $\begin{array}{l}10.95(5.38- \\
24.25)\end{array}$ \\
\hline Midpiece\&Tail, \% & $0.49(0.59)$ & $\begin{array}{l}0.50(0.00- \\
1.50)\end{array}$ & $0.49(0.65)$ & $\begin{array}{l}0.50(0.00- \\
1.50)\end{array}$ & $0.61(0.68)$ & $\begin{array}{l}0.50(0.00- \\
2.00)\end{array}$ \\
\hline $\begin{array}{l}\text { Head\&Midpiece\&Tail, } \\
\%\end{array}$ & $2.73(1.95)^{\mathrm{ac}}$ & $\begin{array}{l}2.50(0.50- \\
6.50)\end{array}$ & $4.38(2.48)^{a b}$ & $\begin{array}{l}4.00(1.50- \\
9.50)\end{array}$ & $5.61(3.07)^{\mathrm{bc}}$ & $\begin{array}{l}5.13(1.50- \\
11.58)\end{array}$ \\
\hline
\end{tabular}

Note. SD - standard deviation; (5-95) - 5th-95th percentile.

Same superscripts in different columns denote differences in mean values by Duncan test:

between men with normospermia and astenozoospermia: $a-p<0.05$;

between astenozoospermia and oligoastenozoospermia $b-p<0.05$;

between normospermia and oligoastenozoospermia c $-p<0.05$.

\section{Supplementary Files}

This is a list of supplementary files associated with this preprint. Click to download.

- Additionalfile1Kleshchevetal.xlsx

- Additionalfile1Kleshchevetal.xlsx 